\title{
DROP EVERTHING AND READ (DEAR) ACTIVITY AS A MEANS OF INCREASING STUDENTS' READING HABITS
}

\author{
${ }^{1}$ Dian Islami Prasetyaningrum, ${ }^{2}$ Hafida Ruminar \\ Universitas Brawijaya Malang \\ dianislami@ub.ac.id
}

\begin{abstract}
Positioned at the bottom two for the literacy level globally, Indonesia needs to find a breakthrough to boost people's reading habits. Reading is a complex process on how readers embracing the written text as a communication media, interpreting the text using the prior knowledge, then finally re-communicate the content as the prove of comprehension. Many students thought that reading was not enjoyable, so the concept of reading for pleasure could help. This present study conducted to show how the Drop Everything and Read (DEAR) approach was helpful to boost the students' habits in reading with pleasure. Many previous studies conducted on several levels of education for instance primary and secondary. So, in this study, the participants were university students who joined English for Specific Purposes (ESP) class. DEAR only needed to be implemented only for 30 minutes regularly, and then the students find out that the approach was helpful to ease their burden in reading. Moreover, the reading for pleasure concept offered in the approach implementation surely makes the students feel the joy of reading that mostly forgotten.
\end{abstract}

Keywords: reading comprehension, Drop Everything and Read (DEAR), reading for pleasure, reading habit

\section{INTRODUCTION}

The need to boost literacy in Indonesia must be acknowledged. It is not surprising that many educators are struggling to find the best way to grow the reading habit. Many students required to read many books and articles academically, but the fact shows that some of them are reluctant readers who can read but they do not read (Pandian, 2000). This case requires the lecturer to find the best way in solving the students' challenges, particularly in reading. Reading is a process that involves similarly complicated skills involving several readers (Mancilla-Martinez \& Lesaux, 2010). A certain strategy should be employed as an effort in giving a positive view of reading.

During the reading, readers employed many other skills such as interpreting, forecasting, questioning, and concluding (Zainal \& Husin, 2011; Küçükoğlu, 2013). Those skills in reading were not an easy task to handle without a good strategy. So that is helping to gain comprehension, finding the best strategy is crucial. Because to comprehend a text, providing the students with only grammatical knowledge is not enough particularly when it is related to some specific fields (Prasetyaningrum, 2018). Beside of comprehension and grammatical, the students also expected to gain vocabulary enrichment during reading. For English for Specific Purposes (ESP) students, being able to tackle those points are important.

In the university setting, non-English department students required to learn English based on their major so that they can both access and spread the knowledge in their area easily (Gayatri, 2018). For example, medical students should learn 
English for medical purposes, while agriculture students should learn English for agricultural science. The necessity to tackle those skills in grammar and vocabulary, also comprehension should be coped wisely so the students will find the benefit of reading simultaneously. Reading is not only an academic activity inside the classroom, but also developing reading habit outside the classroom. In growing the habit, the concept of reading for pleasure needed to be taken into account.

Clark and Rumbold (2006) described reading for pleasure as an interpretive activity based on the experience, expectations, and immediate read environment of readers. The texts chosen in reading for pleasure reflect the readers' own choice. The pleasure aimed to gain the joy of ready experienced by the readers, so the outcomes were the growth of reading habit as well as the improvement of text comprehension. To tackle the reading for pleasure concept, Drop Everything and Read (DEAR) activity might be one of the excellent breakthroughs. DEAR activity is a well-known activity that purposively used in many foreign schools to make reading becomes a routine activity. Increasing the engagement of students with some kind of discourses is the objective. The DEAR program requires the participant of this program to stop doing anything (they have to drop everything) and start reading during a particular time for a particular period.

During the activity, the students decide to choose what text or article they want to read in around 10-15 mins before the class begins. Next, the students need to retell the story of the text/article in brief. The students' ability in retelling the story also known as comprehension. According to Sparks (2012), comprehension also related to the ability to make inferences connected to the prior knowledge in both local and global contexts ideas. So, if the students were able to retell the story and connecting it with their background knowledge, it means they have successfully engaged with the text.

DEAR activity had been implemented previously by Sugiarsih (2017). She assigned her elementary students with this activity to improve the reading comprehension skill. Her research found out that during the activity, students were very happy because they were able to be self-selected their reading with their interest and ability levels. This activity was also proven to be effective in creating a reading culture in the class because students started to be accustomed to the activity. The researcher also believed that DEAR activity would positively improve the students' reading skills.

Some successfulness of DEAR implementation also found in some articles written by Foreign Teachers. Williams (2017) stated that DEAR was a good routine activity implemented at school. It was even paired with 'what's on your bag activity which purposively done to gain more awareness in bringing books to school. Williams found out that DEAR brought up the reading pleasure that triggered the students' reading habits increased higher.

Olivar, et.al (2014) also conducted DEAR activity implementation in the university students. This research implemented to 50 Maritime students to find out the level of importance of the activity implementation. The result showed that the respondents aware of the DEAR purposively helped to improve their communication skills. Also, the respondents agreed that the DEAR made them aware that reading was long-life learning. However, the findings also showed that each student should have proper utilization of the DEAR program to gain effective benefits. 
So, to enrich the sources for DEAR implementation at any level of education, this presents a study objectively conducted to propose a DEAR implementation for ESP students at the university level. The discourses chosen were both printed and digital materials such as storybooks, novels, news, magazines, or other materials based on the students' interest. During the implementation, students have to choose an English text every meeting then they assigned to two tasks. First, they have to retell the text by using their own words. Next, they have to write ten new vocabulary found. By assigning the two tasks, the activity aimed to either enrich the vocabulary or develop the comprehension.

DEAR activity only needs around 15 minutes in each meeting, knowing the class consisted of more than 30 students, all the students need to fill a weekly journal about what they have read. So, this mini research objectively conducted to implement the concept of reading for pleasure to the students through the DEAR activity. Also, to know how well the implementation in helping to grow reading habits in several discourses.

\section{METHOD}

This recent research claimed as qualitative research by using two instruments: classroom observation and interview. The respondents of the research were the first-year students of the Faculty of Agriculture, Universitas Brawijaya Malang who attended English for Agriculture class in the second semester. In this study, three classes randomly selected with a total of 120 students. The lecturer became the observer of the DEAR implementation, to support the observation, the checklist prepared. The checklist consisted of some information on the DEAR implementation during the classroom activity. Also, some notes used for supporting data about the students' active participation. Interview conducted at the end of the semester to cross-check the Weekly journal that mentioned previously also used as documentation that the students did the activity routinely.

There were ten representatives of the class became the respondents for the interview. The interview conducted in the Indonesian language, to make sure that the questions were understandable. The DEAR activity implemented in the first half of the semester, so it started from meeting 2-7. During the implementation, the students freely chose the English discourse they wanted to read. During the DEAR implementation, the students needed to: (1) read the text in 15 minutes, (2) retell the story in sharing session for 10 minutes, and (3) write down 5 new vocabularies found in the text.

\section{DEAR ACTIVITY AND READING FOR PLEASURE}

Knowing the news that Indonesia positioned at the bottom two for the reading interest in 2016, the pressure in finding the best way to improve the students' literacy surely become the consideration for educators. The DEAR activity has been implemented by many foreign teachers at some educational levels for instance primary and secondary school. Since the aim of this activity is making reading as a habitual activity, the higher educational levels are worth considering. Talking academically, reading always becomes quite challenging for some students, particularly when they need to acquire English texts. Moreover, some students also acknowledged as reluctant readers who actually could read but rarely read. So, a 
breakthrough was needed to solve the situation. Promoting reading for pleasure through a DEAR activity could be one of the solutions.

In this recent study, the DEAR activity implemented in the half-semester. DEAR applied in the classroom setting for only 30 minutes in every meeting before the lesson begins. During the implementation, everyone should leave their activity and start reading for about 15 minutes. Students are assigned to read any text such as entertainment, news, politics, short story, novels, and so on. The students can freely choose what they want to read. After 15 minutes, the sharing session started. In the sharing session, the lecturer must actively encourage some students to speak up about the discourse they have read. The sharing intentionally has done to confirm what kind of information they conveyed during reading. So, the lecturer may also check whether they truly understand or not about the text.

After the sharing session, the students need to continue to write down the new vocabularies found from the text. This activity aimed to enrich the English vocabulary repertoire of the students. So, in reading, not only information conveyed, but also new words can be attained. To confirm the participation, the weekly journal must be submitted. The weekly journal included a brief explanation of the text and also new vocabulary found during reading. The submission of the journal makes the lecturer easily re-check the students' DEAR activity participation. All activities assigned in the DEAR would also make the students used to the routine of reading. Since this activity conducted continuously for 7 meetings at the same time and organized steps, it was good to help the higher education students became used to the reading activity.

University settings were surely different from primary or even secondary levels of education. In the university setting, reading habits should be promoted at least by the lecturer (Gayatri, 2018). The lecturer has a big role to give some spaces for the students to find their interest. Since the students experienced many processes during reading for instance prior knowledge activation, question generation, also mental image construction (Pressley, 2000), so the encouragement needed to be given by the lecturer to grow the positive attitude towards the text. Allow the student to employ reading for pleasure concept surely help in springing up the students' habit in reading.

In the reading pleasure concept, students can freely pick the discourses they intended to read. By giving them the freedom to choose, reading will be much enjoyable. This finding supported by the result of the interview. There were 15 out of 30 students interviewed stated that doing reading in DEAR routinely could help them to build the habit of reading. They felt much comfortable in choosing the story they wanted to read because they could choose their favorite novel and even an article about their favorite recent movie. Reading news also became the favorite preferences for the students. It proved by the interview data showed half the respondents agreed that reading recent news much more enjoyable because they had the background knowledge of the same topics. Choosing the right discourses meant giving the joy of reading the content. So, reading didn't come as a scary task assigned, it became more positive.

Furthermore, the concept of reading for pleasure also close enough to the voluntary reading concept where the readers might freely choose any texts they want to read without limitation. This freedom in choosing the texts would lead to a positive attitude in reading and automatically the reluctant reading would be more 
eager to read. The positive attitude really needed to grow the students' love for reading, as stated by Abdullah et al (2012) that comprehension might improve when the interest was well-developed. During the observation started from the second meeting, the students' participation increased drastically. They showed constant active participation in the class. It portrayed from their eagerness in raising their hand during the sharing session and the routine submission of the weekly journal. In the first meeting, many students were still shy in sharing their comprehension, because some of them were scared to make some mistakes in speaking English. It confirmed with the interview data, 10 students said that during the first meeting they were hesitant to be active in the class because they feel a lack of English skills. But, at second until the last meeting, the students started to be active during the DEAR implementation.

Another data regarding the reading for pleasure, DEAR activity implementation was also proven to help the students felt less burden in reading. At the third meeting, many students became more relaxed during the sharing session, because the active participation increased. There were around 15 students raised their hand in each class to share their comprehension of the texts. To confirm this data, the interviewer asked about the positive changes during the participation in the interview. The results showed that 20 students said, as time went by, they became happier in reading and felt less burden. It made them feel enthusiastic about sharing the story they read to the class.

The data mentioned above showed that reading for pleasure could help to increase the students' eagerness in reading. The eagerness in reading could increase the comprehension because the less pressure the readers felt. The pleasure developed in reading will create a better comprehension including fluency and develop a higher level of general knowledge (Whitten, Labby, \& Sullivan, 2016). During the sharing session, the students' participation increased every meeting. They started to used English in retelling the text although their fluency was just average. In short, the concept of reading for pleasure helped them to be more confidence in both reading as well as speaking in communicating the text. Grosman (2011) stated that the direct contact between human and written text during reading for pleasure with automatically activate some senses, namely sound, touch, and perception to build a sensation in the readers' mind that can trigger the enjoyable during reading activity. From the findings mentioned above, the DEAR activity implementation surely made a frequent reading sensation that yet enjoyable and broaden the reading experiences in many kinds of discourses.

The results of observation showed that in meeting 4-7, students started to get used to with reading before the class began. Many students were confidence enough to be active in class, share their experiences and comprehension. Many of them who were passive, start to show their lively participation in the class. This data strengthens by the interview, 25 students told how enjoyable reading activity through DEAR for them, and they could understand the text better. This result was reinforced by the Diaz (2016) statement by suggesting that the faster a person learns, the more text is covered and, thus, the more general comprehension is achieved.

In short, from the findings, the concept of reading for pleasure gave a positive effect for the students especially in providing the freedom in reading so the joy of reading could be experienced by them. Furthermore, the DEAR activity also 
completed the experience in reading because the students found out that in only 15 minutes, reading could be a fun activity.

\section{DEAR ACTIVITY AND READING HABIT}

Generally, reading habits defined as planned and deliberately study patterns that showed consistency (Acheaw \& Larson, 2014). The consistency created in habit would be developed better with the existence of pleasure in reading and it would support the comprehension as well. Furthermore, Eze (2004) stated that reading habits would positively build up the reading attitudes among students over time. The findings mentioned previously indicated that DEAR activity could positively support the habit empowerment in reading.

Improving students' reading habit through DEAR activity could also improve the students' ability in conveying the information quickly. The more students exposed to the various kind of text; the more positive attitudes gained towards reading. Growing reading habits was surely necessary in helping the students improving their comprehension in a pleasurable way. Supported by Tella and Akande (2007), someone who developed a good reading habit would automatically develop the mindset and believed that reading is a pleasurable, frequent, and constant practice.

During the DEAR implementation, students started to be used to reading activity though the lecturer struggled to instruct them to read at first because many of them were reluctant readers. It was a challenge at first. However, in the second meeting, students started to read without further instruction. During the sharing session, many students showed better participation by the time. The most challenging thing for the students was retelling the story of the texts because they were not from the English department, so the proficiency just so-so.

The positive thing during the implementation was the lecturer's role in helping the passive students to talk and share their experience in reading. It was a good move to build the students' positive view and confidence toward the DEAR implementation. So, there were no students who felt left behind. The respondents of the interview said that "my lecturer helps my friends a lot in the class. Many of them are too shy in speaking up, but my lecturer gives them many chances in sharing their story". Out of 30 respondents, 12 of them stated that the lecturer was the main role during the success of the activity because she did not only focus on the smart students but also the other students who considered passive. This act added more positive values during the DEAR implementation and automatically brought an enjoyable classroom atmosphere.

For supporting the reading habits, the result of the interview also proved that all the respondents agreed that the DEAR implementation trained them to get used to reading. "I am getting used to reading any texts that easy for me. So, it is not scary at all" they said. Additionally, spending around 10-15 minutes for reading helped them to grow awareness that reading was important for them. The freedom to choose a suitable text to read led them to feel that reading is a pleasurable activity, so growing the habit in reading is not a difficult task for the students.

The increasing and enthusiasm of students in improving reading habits were also seen in the weekly journals. The weekly journal was an instrument used during DEAR activities for half of the semester, to support and monitor the DEAR implementation. In weekly journals, students required to write some points, such as 
the title of the text they read, the brief summary, and finally ten new vocabularies. The students must submit the journal every week. The weekly journal effectively checked the reading track done by the students during the implementation. Figure 1 showed an example of the weekly journal that must be collected during DEAR implementation.

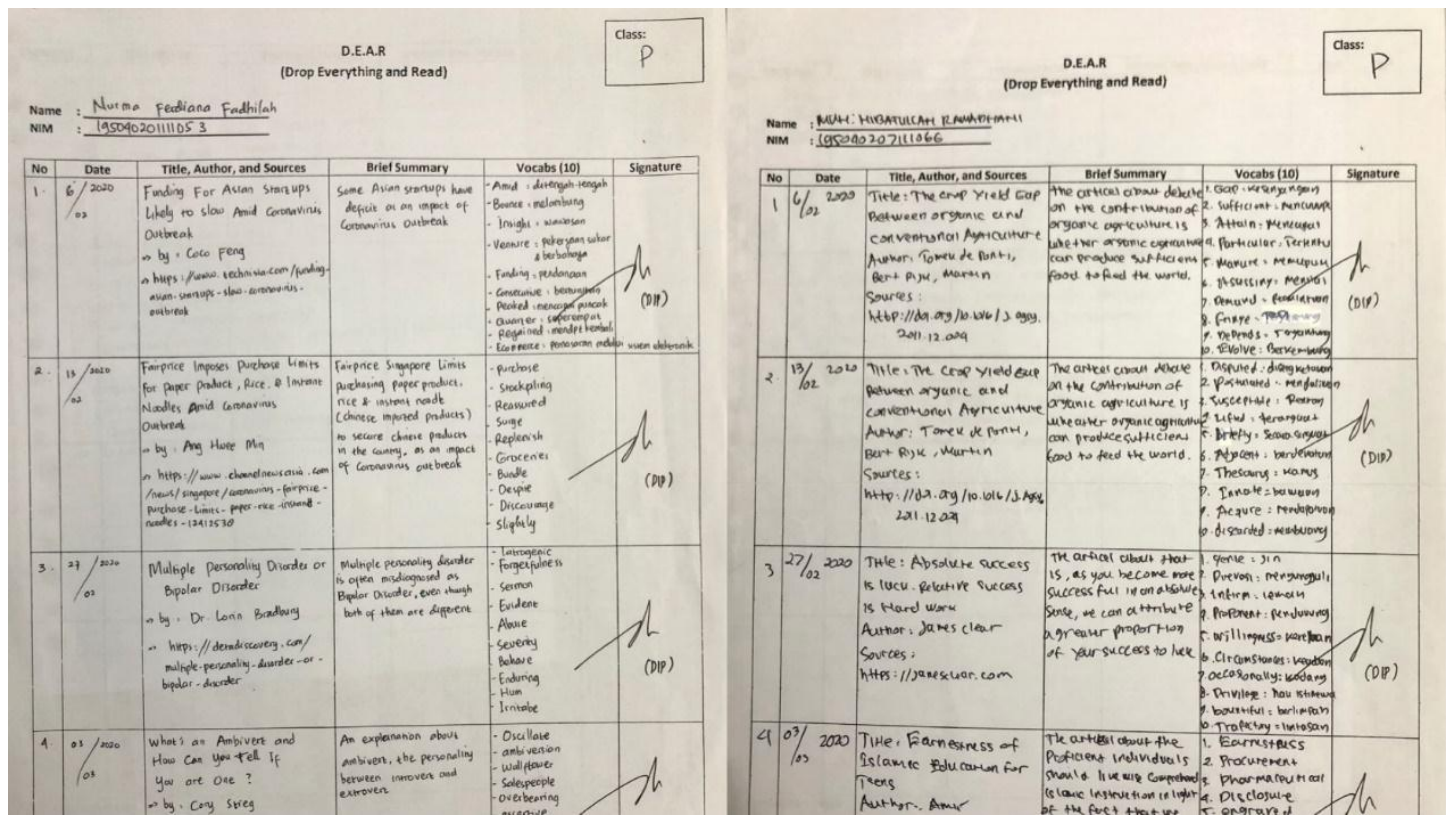

Figure 1. The Weekly Journal submitted by the students during DEAR implementation

One point of the weekly journal was the summary. The summary aimed to check the students' brief comprehension of the text. Still, with the concept of reading for pleasure, this task should be assigned with no burden. The summary activity proved to be able to measure reading comprehension. Because with summarizing, the students tried to demonstrate the comprehension of the text they had read. Moreover, the brief summarizing activity gave the students more time in practice to communicate with their own words. The integrated reading and writing activity revealed a positive correlation particularly in either summary writing or reading comprehension (Mokeddem \& Houcine, 2016).

Additionally, Ozdemir (2018) also studied the power of summarization strategies in helping the students' reading comprehension. He argued that summarizing should be given in the reading class because it could be an indication of the comprehension level. The results of the present study also showed that summarizing was able to check the students' comprehension besides communicating the idea verbally. During the DEAR implementation, to crosscheck the students' reading, the lecturer also checks the summary in the weekly journal. Some respondents stated that writing a summary made them feel easier to cope with the idea of the text. Some of them also confirmed that "the summary concept, makes me feel less burden when reading because I need to write a short paragraph. I enjoy doing a DEAR activity". It showed that the simplicity brought during the DEAR implementation, including the reading activity, sharing session, 
and the weekly journal helped the students to increase their love in reading, and constantly would raise their habits in reading.

\section{CONCLUSION}

Shortly, growing reading habits could be done by applying DEAR activity and let the students freely choose they wanted to read in just 10-15 minutes. In the implementation, the lecturer also played a significant role in helping the students to be more active and erase their reluctant in reading. Pleasure given by reading would also lead to the growth of the positive point of view towards reading. By the positive attitudes, the reading habit will increase as well as comprehension. The DEAR activity can be used as an icebreaking activity before the class begins. The lecturer only needs around 30 minutes to apply this activity, but the continuous implementation gives the best effect in increasing the students' reading habits.

Additionally, the weekly journal also proves to be effective in tracking the students reading progress. So, it makes the lecturer easier to track the students' progress during the DEAR implementation. Moreover, the lecturer will also find a broad view about what kind of topic and text the students spend the most time reading. Many respondents also state that the less burden during the DEAR implementation makes them enjoy reading more, and they start to build a positive attitude towards reading. This means, the concept of reading for pleasure during the DEAR implementation considers successful to boost the students' positivity in reading as well as develop the reading habits.

Since the study considered a pilot study, a further researcher who is interested in the same area may use the quantitative analysis to give statistical data in proving the effectiveness of the DEAR implementation in reading. Gender differences also can be used as the supporting data to show the different attitudes of female and male students toward reading comprehension activity. The correlation between reading comprehension and writing also can be studied further.

\section{REFERENCES}

Abdullah, S., Rahim, P. R. M. A., Setia, R., Mohamad, R., Ghazali, N., Sabapathy, E., Nair, G. K. S., Muniandy, M. K., Theethappan, R., Hassan, W. A. W., \& Hassan, N. S. I. C. (2012). Reading for Pleasure as a Means of Improving Reading Comprehension Skills. Asian Social Science; 8 (13).

Acheaw, M.O.\& Larson, A. (2014). Reading habits among students and its effect on academic performance: A study of students of Koforidua Polytechnic. Library Philosophy and Practice (e-journal). Paper 1130. viewed n.d., from http:// digitalcommns.unl.edu/libphilprac/1130. Date access: 26 July 2020.

Clark, C. \& Rumbold, K. (2006). Reading for Pleasure: A Research Overview. London: National Literacy Trust.

Diaz, C.F. (2016). The Impact of Pleasure Reading in English as a Second Language on Colombians who have a Postgraduate Level of Education. British Council ELT Master's Dissertation Awards: Commendation. Retrieved from: https://englishagenda.britishcouncil.org/sites/default/files/attachments/mda2 017_bath_spa_university_camila_fuentes_diaz.pdf. Date access: 26 July 
2020.

Eze, C. C. (2004). The need for effective teaching of the use of library in Nigeria Universities. The Nigerian Library link II, 67-50.

Gayatri, P. (2018). Adapting Drop Everything and Read (DEAR) Program to Enrich ESP Students' Vocabulary. PROSPECTS, Jurnal Humaniora, Sains, Pendidikan dan Pengajaran, 8 (2), 17-21.

Grosman, M. (2011). Readers and Reading as Interaction with Literary Texts. Perspectives of Reading Research, 34(2), 157-171.

Küçükoğlu, H. (2013). Improving Reading Skills through Effective Reading Strategies. Procedia-Social and Behavioral Sciences, 70, 709-714.

Mancilla-Martinez, J. \& Lesaux, N. (2010). Predictors of Reading Comprehension for Struggling Readers: The Case of Spanish-Speaking Language Minority Learners. Journal of Educational Psychology, 102(3), 701-711.

Mokeddem, S., \& Houcine, S. (2016). Exploring the Relationship between Summary Writing Ability and Reading Comprehension: Toward an EFL Writing-to-Read Instruction. Mediterranean Journal of Social Sciences, 7(2), 197-205.

Olivar, L.L., Manalo, J. A., Palma, A. M., Ramirez, V. H., Gemino, K. L., Caiga, B. T. (2014). Awareness of Maritime Students in Lyceum International Maritime Academy on the Drop Everything and Read (DEAR) Program. Academic Research International Vol. 5(3) May 2014.

Odzemir, S. (2018). The Effect of Summarization Strategies Teaching on Strategy Usage and Narrative Text Summarization Success. Universal Journal of Educational Research 6(10): 2199-2209, 2018.

Pandian, A. (2000). A study on readership behavior among multiethnic, multilingual Malaysian students. A paper presented at the seventh International literacy and education research network (LERN) Conference on Learning, RMIT University, Melbourne, 5-9 July 2000.

Prasetyaningrum, D.I. (2018). Improving Agriculture Students' Reading Comprehension through Task-Based Language Teaching (TBLT). EnJourMe (English Journal of Merdeka): Culture, Language, and Teaching of English 3(1) $5-14$.

Pressley, M. (2000). What should comprehension instruction be the instruction of? Handbook of Reading Research, 3, 545-559.

Sugiarsih, S. (2017). Peningkatan Keterampilan Membaca Melalui Drop Everything and Read (DEAR) pada Siswa Sekolah Dasar (MI) Al-Bidayah. Jurnal Pendidikan Dasar Islam. 9 (2).

Sparks J.R. (2012). Language/discourse comprehension and understanding. Encyclopedia of the Learning Sciences. 1713-1717. Springer.

Tella, A. and Akande, S. (2007). Children's reading habits and availability of books in Botswana primary schools: implications for achieving quality education. The reding matrix. Library Philosophy and Practice. Retrieved fromhttp://www.redingmatrix.com/article/adeyinka/article/pdf. Date access: 26 July 2020.

Whitten, C., Labby, S., \& Sullivan, S. (2016). The Impact of Pleasure Reading on 
Drop Everything and Read (DEAR) Activity as a Means of Increasing Students'

Reading Habits

Academic Success. The Journal of Multidisciplinary Graduate Research, 2(4), 48-64.

Williams, F.L. (2017). If you do one thing, make sure it's drop everything and read (DEAR).

Retrieved

from

https://educationblog.oup.com/secondary/english/if-you-do-one-thing-

make-sure-its-drop-everything-and-read-dear. Date access: July $20^{\text {th }} 2020$

Zainal, Z. \& Husin, S. (2011). A Study on the Effects of Reading on Writing Performance among Faculty of Civil Engineering Students. Journal of Science \& Mathematics Education, 1-8. 